\title{
CORRECTION
}

Check for updates

Cite this: New J. Chem., 2017, 41,4241

DOI: 10.1039/c7nj90035j

rsc.li/njc

\section{Correction: Diiridium(III) complexes: luminescent probes and sensors for G-quadruplex DNA and endoplasmic reticulum imaging}

\author{
Tikum Florence Anjong, Gyoungmi Kim, Ha Yoon Jang, Juyoung Yoon* and \\ Jinheung Kim*
}

Correction for 'Diiridium(III) complexes: luminescent probes and sensors for G-quadruplex DNA and endoplasmic reticulum imaging' by Tikum Florence Anjong et al., New J. Chem., 2017, 41, 377-386.

The authors wish to highlight several previous studies, ${ }^{1-5}$ which should have been cited in the Introduction of this New Journal of Chemistry paper. These references describe the use of inorganic compounds based on the G-quadruplex structure for DNA binding and detection.

The Royal Society of Chemistry apologises for these errors and any consequent inconvenience to authors and readers.

\section{References}

1 S. Liu, H. Liang, K. Y. Zhang, Q. Zhao, X. Zhou, W. Xu and W. Huang, A multifunctional phosphorescent iridium(III) complex for specific nucleus staining and hypoxia monitoring, Chem. Commun., 2015, 51, 7943-7946.

2 C. Rajput, R. Rutkaite, L. Swanson, I. Haq and J. A. Thomas, Dinuclear monointercalating Ru ${ }^{\text {II }}$ complexes that display high affinity binding to duplex and quadruplex DNA, Chem. - Eur. J., 2006, 12(17), 4611-4619.

3 M. R. Gill, J. Garcia-Lara, S. J. Foster, C. Smythe, G. Battaglia and J. A. Thomas, A ruthenium(II) polypyridyl complex for direct imaging of DNA structure in living cells, Nat. Chem., 2009, 1(8), 662-667.

4 T. Wilson, M. P. Williamson and J. A. Thomas, Differentiating quadruplexes: binding preferences of a luminescent dinuclear ruthenium(II) complex with four-stranded DNA structures, Org. Biomol. Chem., 2010, 8(11), 2617-2621.

5 T. Wilson, P. J. Costa, V. Félix, M. P. Williamson and J. A. Thomas, Structural studies on dinuclear ruthenium(II) complexes that bind diastereoselectively to an antiparallel folded human telomere sequence, J. Med. Chem., 2013, 56(21), 8674-8683. 